\title{
Strategy to Reduce GHG Emission and Energy Consumption at Process Production of Biodiesel Using Catalyst From Crude Palm Oil (CPO) and Crude Jatropha Curcas Oil (CJCO) in Indonesia
}

\author{
Kiman Siregar \\ Agricultural Engineering Department, Syiah Kuala University, Jl.Tgk.Hasan Krueng Kalee No.3, Banda Aceh, 23111, Indonesia \\ E-mail: ksiregar.tep@unsyiah.ac.id
}

\begin{abstract}
Crude palm oil (CPO) is one kind of biologic resource that has been widely produced for biodiesel fuel, including Indonesia as the world main producer of palm oil. However, CPO is a food resource. This drives Indonesia to find another alternative source for biodiesel production. One promising source is Jatropha curcas $\mathbf{L}$. which is considered as non-edible industrial plant used for biodiesel fuel. Jatropha curcas could be planted in marginal soil, semi dry climate, and suitable in tropical and subtropic climate. According to those aforementioned situations, an effort to address this issue should be conducted by identifying and presenting actual condition of Indonesian palm oil and Jatropha curcas estate. In this research, LCA is used to analyze the prospect of oil palm and Jatropha curcas development. The impact assessment calculation on stable production is lower than before-stable production. By considering that $4 / 5$ or 20 years of 25 years of its life cycle lie on stable production, appropriate calculation method is needed. Agrochemical utilization such as fertilizer, insecticides, pesticides, and fungicides produces significant contribution to environmental impact in biodiesel production. It is accounted by $\mathbf{5 0 . 4 6 \%}$ for oil palm and $33.51 \%$ for Jatropha curcas. The use of organic fertilizer very influences the reduction of GHG emission value in fertilization sub-process. It could reduce up to $96.2 \%$ for oil palm and $76.8 \%$ for Jatropha curcas. In term of electricity generation, shows that Jatropha curcas oil based biodiesel is better than fossil fuel. The improvement of Indonesian power plant should consider the utilization of low GHG emission fuel, such as natural gas and biodiesel fuel.
\end{abstract}

Keywords - GHG emission; biodiesel; organic fertilizer; crude palm oil; crude jatropha curcas oil.

\section{INTRODUCTION}

\section{A. Background}

In terms of its resource, biodiesel could be claimed as renewable energy. However, various activities and material as well as energy input to the production chain could abandon its renewability status if poorly managed. Biodiesel can be produced from various feed stocks. Due to its availability and suitability, Indonesia mainly uses oil palm (Elaeis guineensis) and jatropha (Jatropha curcas L) as biodiesel feedstock. This is rational since Indonesia is one of main oil palm producer in the world. On the other hand, jatropha is a non-edible industrial crop and easily grown at various part of Indonesia, that makes it as good alternative for biodiesel fuel production [14]. Each of the plants has its own characteristics along its production chain to be used as biodiesel feedstock.

Accordingly, life cycle assessment (LCA) of biodiesel production from each of the oil producing plants needs to be conducted in order to compare its state of renewability. Life cycle assessment (LCA) is a systematic tool for assessing the environmental impacts associated with any products, processes and activities [1], which is standardized in ISO 14000 series. The LCA needs elaboration of data in terms of life cycle inventory (LCI) to obtain a rational result of the assessment. The result of LCA is highly influenced by the reliability and sufficiency of data inventory of the assessed object. Data collection process is the main focus in inventory analysis and the most time-consuming process of all LCA process [11].

Unfortunately, despite of its high potentiality in providing the biodiesel feedstock, date accessibility in Indonesia is still very limited for a comprehensive LCA study. A number of LCA studies on biodiesel production using feedstock from Indonesia have been conducted. However, results discrepancy generated in the studies are due to inconsistency of the data used. Accordingly, continuous studies are indispensable to be conducted in order to perform a comprehensive LCA study on biodiesel production from oil palm and jatropha produced in Indonesia. 


\section{B. Objective And Problem Formulation}

The objective of the research is to analyze and compare Life Cycle Assessment (LCA) of oil palm and Jathropa curcas as feedstock for biodiesel in Indonesia from cradle to gate using data based found in Indonesia, and to find strategy to reduce of value of green house gas emission and energy consumption.

According to those aforementioned situations, scientific approach needs to be taken in order to answer the problem related with global warming emission and others environmental effect along its biodiesel production path from palm oil and Jatropha curcas. Reducing emission value generated from oil palm and jathropa curcas for biodiesel production is important to be determined in order to meet the standard of global market. The following questions have been formulated from the previous problem in systematic and structured study to provide good result: (1) What is the emission distribution for planting, harvesting and post-harvesting of palm oil and Jathropa curcas-based biodiesel? Which stage has significant effect? What kind of material input is the most siqnificant increasing the global warming potential emission value? (2) How are the energy consumption, net energy balance, net energy ratio, and renewable index of biodiesel production from palm oil and jathropa curcas? (3) How much is the potentialing in reducing green house gas (GHG) emission generated from palm oil and jathropa curcas-based biodiesel compared to diesel-fuel one?

It is expected that the research could give solution and describe the net energy balance and net energy ratio for further development of biodiesel processing.

\section{Methodology}

The system boundary for LCA study is shown in Fig.1, which is a cradle to gate assessment. The production cycle to be assessed consists of eight sub-processes. The functional unit (FU) of this study is 1 ton of biodiesel fuel (BDF) production from jatropha and oil palm. Data to be used in this study was from oil palm plantation in PTPN VIII Unit Kebun Kertajaya Lebak Banten and from Jatropha curcas centre Pakuwon Sukabumi West Java. Both locations are in Jawa island of Indonesia.

Life cycle inventory analysis was performed on the material and energy inputs, air emission, waterborne emission, and solid wastes involved in biodiesel production from each oil plants. Each stage of analysis and calculations was carried out before and after the plants yield the usable fruits. Based on the field survey, oil palm and jatropha will have stable productivity after $5^{\text {th }}$ years from seed plantation. The first production of palm oil occurs at 30 months old, while Jatropha curcas at 4 months after plantation.

Transportation from seed from nursery to plantation area was assumed to be as the distance from the centre point of the plantation, which was $30 \mathrm{~km}$, using 5 tons capacity truck with 1 liter diesel oil consumption per each $5 \mathrm{~km}$. Transportation of fruits from harvesting area to palm oil mills was $150 \mathrm{~km}$, using 10 tons capacity truck, with 1 liter diesel oil consumption per $7 \mathrm{~km}$ travel. Transportation from palm oil mills to biodiesel plant was $200 \mathrm{~km}$, using 10 tons capacity truck.



Fig.1. The system boundary of this study

\section{RESULTS AND DISCUSSION}

\section{A. Life Cycle Inventory}

The LCI was conducted based on input-output analysis of mass and energy to each of the production line, as shown in Fig.1. Detail description of eight sub-processes involved in LCI for oil palm and jatropha is shown in Table 1. Comparison of material and energy used for 1 ton production of palm oil and jatropha based biodiesel is shown in Table 2 [8];[2]. Stable productivity of palm oil at PTPN VIII is approximately at 21.5 tons per ha [9]; [5]; [10], while jatropha has stable productivity at about 8 tons per ha for IP3-P [8]. Production amount of biodiesel from palm oil and Jatropha curcas oil during its life cycle ( 25 years) is shown in Fig. 2. From this figure it can be seen that stable productivity of each crops will be obtained at the $5^{\text {th }}$ years.

Weeds population in palm oil estate is higher than in jatropha plantation, which needs more effort to control. This fact is the reason for higher herbicide requirement for oil palm plantation than for jatropha, as shown in Table 2. The height of seeds lived surrounding palm seedlings is approximately $1.5 \mathrm{~m}$ while Jatropha curcas tree is approx. $0.5 \mathrm{~m}$. Oil palm also needs more diesel fuel than jatropha 
due to the requirement of mechanical tillage for oil palm plantation. On the other hand, jatropha plantation needs less tillage for the plant more resistant to critical environmental conditions.

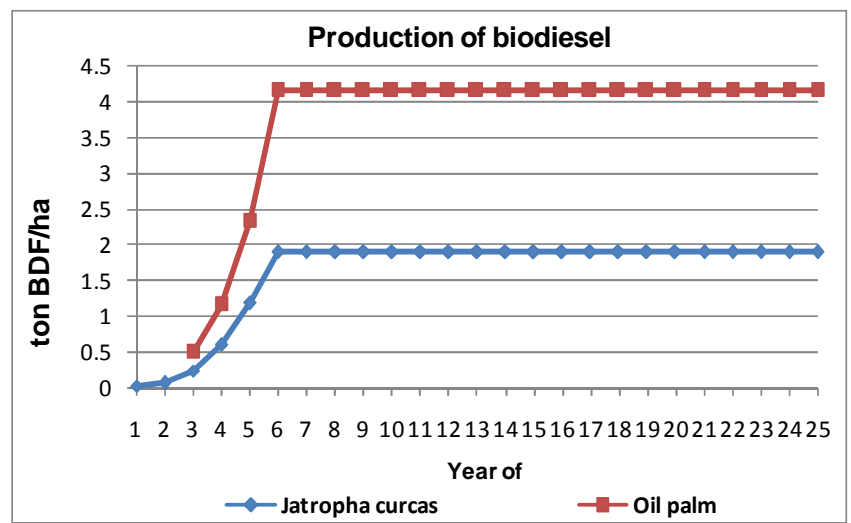

Fig.2. Productivity of biodiesel per ha from palm oil and Jatropha curcas oil

At nursery stage, oil palm plantation uses higher amount of pesticides and fertilizer due to longer seedling process (12 months) compared to jatropha plantation (3 months). Palm oil seedling consists of growth stage of seedlings and seedling nursery which need intensive amount of fertilizers and pesticides. However, jatropha needs more application of fertilizer during planting stage, since the number of trees per hectare of jatropha plantation is larger (2500 trees) than oil palm (136 trees) [2]; [13]; [5].

The table also shows that during the first five years growth, oil palm plantation needs more fertilizer, as well as other agro-chemicals for protection, than the jatropha plantation. Oil palm is more susceptible to plant pests than jatropha. Dose application will change continuously based on plant's requirement, which is analyzed and determined by soil and leaves nutrient needs. This analysis will give the appropriate amount of fertilizer and protection agrochemicals. From Table 2 can also be seen that the Jatropha curcas more use of organic fertilizer and pospate fertilizer than oil palm in its growth.

Jatropha curcas grown in Indonesia is known as poisonous plant so it has high resistance to pest and disease attack. It is probably caused by the planting system that is generally mixed with other plants such as gamal (glyrecidiamaculata) and waru. If planting is conducted in monoculture system with wide space to others plants it might result the occurrence of pests and diseases.

At the stage of harvesting sub-process, the transport energy uses for oil palm is higher than Jatropha curcas due to the differences of harvesting yield. The yield of oil palm is higher than Jatropha curcas. In the case of crude oil production, Jatropha curcas oil needs only electricity and diesel fuel for its process. On the other hand, palm oil mills need more materials and energy. At the stage of biodesel production sub-process, due to high average value of free fatty acids (FFA) in jatropha curcas oils, it needs esterification stage before trans-esterification. Consequently, jatropha curcas oils needs more materials and energy.
TABLE I

THE COMPARISON OF BIODIESEL PRODUCTION FROM CPO AND CJCO WITH BOUNDARY CRADLE TO GATE

\begin{tabular}{|c|c|c|c|}
\hline $\begin{array}{c}\text { Input } \\
\text { activities }\end{array}$ & Component & Oil palm & \begin{tabular}{|c|} 
Jathropa \\
curcas \\
\end{tabular} \\
\hline $\begin{array}{l}\text { (1) Land } \\
\text { preparation }\end{array}$ & $\begin{array}{l}\text { Early land uses } \\
\text { Soil fertility } \\
\text { Tree, diameter } \\
>60 \mathrm{~cm} \\
\text { Tree, diameter } \\
>30 \mathrm{~cm} \\
\text { Coarse grass } \\
\text { Soil tillage } \\
\\
\text { Plant above the soil } \\
\text { surface }\end{array}$ & \begin{tabular}{|l|} 
Primer \\
skunder forest \\
Fertile \\
$26-100$ \\
trees/ha \\
Approx. 2500 \\
trees/ha \\
$10-30$ \\
groups/m2 \\
Effective soil \\
depth $50-150$ \\
cm \\
Nuts
\end{tabular} & \begin{tabular}{|l|} 
Coarse \\
grass forest \\
Less fertile \\
No trees \\
Approx. \\
500 \\
$10-30$ \\
groups/m2 \\
Effective \\
soil depth \\
$20-30$ cm \\
No plants, \\
usually \\
\end{tabular} \\
\hline (2) Seedling & \begin{tabular}{|l|} 
Seedling time \\
Seedling source \\
\end{tabular} & $\begin{array}{l}12 \text { months } \\
\text { Seed }\end{array}$ & \begin{tabular}{|l|}
3 months \\
Seed, steck \\
\end{tabular} \\
\hline (3) Planting & $\begin{array}{l}\text { Plants width space } \\
\text { Number of plants } \\
\text { Number of hole }\end{array}$ & \begin{tabular}{|l|}
$9 \times 9 \times 9 \mathrm{~m}$ \\
$136 / \mathrm{ha}$ \\
$50 \times 40 \times 40 \mathrm{~cm}$ \\
\end{tabular} & $\begin{array}{l}2 \times 2 \times 2 \mathrm{~m} \\
2500 / \mathrm{ha} \\
40 \times 40 \times 40\end{array}$ \\
\hline (4) $F$ & $\begin{array}{l}\text { Fertilizer compound } \\
\text { Intensity }\end{array}$ & $\begin{array}{l}\mathrm{N}, \mathrm{P}, \mathrm{K}, \mathrm{Mg}, \mathrm{B}, \\
\text { organic } \\
\text { Very } \\
\text { intensive }\end{array}$ & $\begin{array}{l}\mathrm{N}, \mathrm{P}, \mathrm{K}, \\
\text { organic } \\
\text { Scarcely } \\
\text { conducted }\end{array}$ \\
\hline (5) Prot & Plant & \begin{tabular}{|l|}
$\begin{array}{l}\text { Many kinds } \\
\text { of pest }\end{array}$ \\
\end{tabular} & \begin{tabular}{|l|} 
Almost not \\
present
\end{tabular} \\
\hline (6) $\mathrm{H}$ & \begin{tabular}{|l|} 
Start to produce \\
Production on \\
stable productivity \\
Edible/non-edible
\end{tabular} & \begin{tabular}{|l|}
30 months \\
8 tons seed/ha \\
Edible
\end{tabular} & \begin{tabular}{|l|}
4 months \\
21.5 tons \\
FFB/ha \\
Non-edible
\end{tabular} \\
\hline $\begin{array}{l}\text { (7) Palm oil } \\
\text { mills or } \\
\text { Extraction oil }\end{array}$ & $\begin{array}{l}\text { Production of crude } \\
\text { oil } \\
\text { Value of FFA } \\
\text { Ratio of FFB to } \\
\text { crude oil } \\
\text { Produced biomass }\end{array}$ &  & \begin{tabular}{|l|} 
By \\
extraction \\
$>2$ \\
$26 \%$ \\
\\
Kernel \\
pulp, shell, \\
jathropa oil \\
cake
\end{tabular} \\
\hline $\begin{array}{l}\text { (8) Biodiesel } \\
\text { production }\end{array}$ & $\begin{array}{l}\text { Reaction of } \\
\text { biodiesel } \\
\text { production } \\
\text { Ratio of crude oil to } \\
\text { BDF } \\
\text { Biodiesel source } \\
\text { Catalyst }\end{array}$ & \begin{tabular}{|l|} 
Transesterific \\
ation \\
$92 \%$ \\
Pulp, kernel \\
Alkali
\end{tabular} & \begin{tabular}{|lr|}
\multicolumn{2}{|l|}{ Esterificati } \\
on & and \\
transesterifi \\
cation \\
$91 \%$ \\
\\
kernel \\
Acid \\
alkali
\end{tabular} \\
\hline
\end{tabular}


TABLE II

MATERIALS AND ENERGY FOR 1 TON BDF FROM JATROPHA CURCAS AND PALM OIL

\begin{tabular}{|c|c|c|c|c|}
\hline $\begin{array}{c}\text { Input } \\
\text { activities }\end{array}$ & Inpu & Unit & Palm oil & $\begin{array}{l}\text { atropha } \\
\text { curcas }\end{array}$ \\
\hline $\begin{array}{l}\text { (1) Land } \\
\text { preparation }\end{array}$ & $\begin{array}{l}\text { Herbicide } \\
\text { Diesel fuel for toppling \& cleari }\end{array}$ & $\begin{array}{l}\mathrm{kg} \\
\mathrm{L}\end{array}$ & $\begin{array}{l}0.861 \\
0.703\end{array}$ & $\begin{array}{l}0.624 \\
1.208\end{array}$ \\
\hline See & $\begin{array}{l}\text { Fungicides } \\
\text { Insecticides } \\
\text { Chemical fertilizer Urea } 0,2 \% \\
\text { Organic fertilizer } \\
\text { Kieserite (MgSO4) } \\
\text { Urea } \\
\text { Herbicide } \\
\text { Dolomite } \\
\text { Compound fertilizer } \\
\text { Electricity for Pump Water } \\
\text { Pesticides }\end{array}$ & \begin{tabular}{l|}
$\mathrm{kg}$ \\
$\mathrm{kg}$ \\
$\mathrm{kg}$ \\
$\mathrm{kg}$ \\
$\mathrm{kg}$ \\
$\mathrm{kg}$ \\
$\mathrm{kg}$ \\
$\mathrm{kg}$ \\
$\mathrm{kg}$ \\
$\mathrm{kWh}$ \\
$\mathrm{kg}$
\end{tabular} & $\begin{array}{r}0.00018 \\
0.00492 \\
8.367 \\
2.008 \\
0.000067 \\
0.974 \\
2.949 \\
4.686 \\
0.436 \\
0.004 \\
1004\end{array}$ & $\begin{array}{r}0.852 \\
0.0057\end{array}$ \\
\hline \begin{tabular}{|l|} 
Transportation \\
(3) Planting
\end{tabular} & $\begin{array}{l}\text { ertilizer } \\
\text { sphate }\end{array}$ & \begin{tabular}{|l|}
$\mathrm{L}$ \\
$\mathrm{kg}$ \\
$\mathrm{kg}$ \\
$\mathrm{kg}$
\end{tabular} & $\begin{array}{r}1.004 \\
13.387 \\
- \\
22.887\end{array}$ & $\begin{array}{r}1.189 \\
79.562 \\
994.524 \\
- \\
15.912\end{array}$ \\
\hline $\begin{array}{l}\text { (4) Fertilizing } \\
\text { for five years }\end{array}$ & $\begin{array}{l}\text { losphate } \\
\text { a } \\
\text { orate } \\
36 \\
\text { ) } / \mathrm{KCl} \\
\text { rate } \\
\text { fertilizer }\end{array}$ & $\begin{array}{l}\mathrm{kg} \\
\mathrm{kg} \\
\mathrm{kg} \\
\mathrm{kg} \\
\mathrm{kg} \\
\mathrm{kg} \\
\mathrm{kg} \\
\mathrm{kg} \\
\mathrm{kg}\end{array}$ & $\begin{array}{r}9.844 \\
252.492 \\
279.464 \\
3.347 \\
117.140 \\
245.995 \\
184.078 \\
3.347\end{array}$ & $\begin{array}{r}87.518 \\
- \\
278.467 \\
95.474 \\
- \\
- \\
994.524\end{array}$ \\
\hline $\begin{array}{l}\text { (5) Protection } \\
\text { for five years }\end{array}$ & des (liquid \& powder) & $\begin{array}{l}\mathrm{kg} \\
\mathrm{kg} \\
\mathrm{kg} \\
\mathrm{L}\end{array}$ & $\begin{array}{r}56.317 \\
1.323 \\
0.801 \\
0.554 \\
\end{array}$ & 2.955 \\
\hline \begin{tabular}{|l|} 
(6) Harvesting \\
Transportation \\
\end{tabular} & & $\mathrm{L}$ & 5.027 & 2.468 \\
\hline $\begin{array}{l}\text { (7) Palm oil } \\
\text { mills vs Oil } \\
\text { extraction }\end{array}$ & $\begin{array}{l}\text { Electricity } \\
\text { Steam consumption } \\
\text { Water consumption } \\
\text { PAC } \\
\text { Flokulon } \\
\mathrm{NaOH} \\
\mathrm{H} 2 \mathrm{SO} 4 / \mathrm{HCl} \\
\text { Tanin Consentrate } \\
\text { Poly Perse BWT } 302 \\
\text { Alkaly BWT } 402 \\
\text { Shell }\end{array}$ & \begin{tabular}{l|}
$\mathrm{kWh}$ \\
$\mathrm{kg}$ \\
$\mathrm{m}^{3}$ \\
$\mathrm{~kg}$ \\
$\mathrm{~kg}$ \\
$\mathrm{~kg}$ \\
$\mathrm{~kg}$ \\
$\mathrm{~kg}$ \\
$\mathrm{~kg}$ \\
$\mathrm{~kg}$ \\
$\mathrm{~kg}$ \\
$\mathrm{~L}$
\end{tabular} & $\begin{array}{r}34.392 \\
325.397 \\
3.968 \\
0.125 \\
0.00053 \\
0.107 \\
0.109 \\
0.045 \\
0.045 \\
0.043 \\
133.862 \\
2.540\end{array}$ & 4.833 \\
\hline $\begin{array}{l}\text { (8) Biodiesel } \\
\text { production } \\
\text { Esterification } \\
\text { Trans- } \\
\text { esterification }\end{array}$ & $\begin{array}{l}\text { Methanol } \\
\mathrm{H} 2 \mathrm{SO} 4 \\
\text { Electricity } \\
\text { Methanol } \\
\text { Electricity } \\
\mathrm{NaOH}\end{array}$ & \begin{tabular}{|l|} 
ton \\
ton \\
$\mathrm{kWh}$ \\
ton \\
$\mathrm{kWh}$ \\
ton \\
$\mathrm{L}$ \\
$\mathrm{L}$ \\
\end{tabular} & $\begin{array}{r}0.269 \\
15.645 \\
0.080 \\
1700.68 \\
14.00\end{array}$ & $\begin{array}{r}0.449 \\
0.027 \\
1.285 \\
- \\
15.645 \\
0.080 \\
1719.180 \\
16.00\end{array}$ \\
\hline
\end{tabular}

\section{B. Impact Assessment}

Impact assessment was carried out using data provided in inventory analysis and in MiLCA-JEMAI (Multiple interface life cycle assessment-Japan enviromental management association for industry) database version 1.1.2.5. Five categories of environmental impacts were interest i.e. global warming potential, acidification, waste for landfill volume, eutrophication, and energy consumption (Table 3). Table 3 shows that total environmental impact before stable productivity for biodiesel production from palm oil is higher than that of Jatropha curcas oil. Global warming potential is the most significant environmental impact caused by biodiesel production either from palm oil or Jatropha curcas oil. Most of the global warming emission emerges from utilization of agrochemical in form of fertilizer and plant protection, i.e. $50.46 \%$ and $33.51 \%$ of total emission of biodiesel produced from palm oil and Jatropha curcas oil, respectively. Other works conducted by Pramudita (2011) and Sekiguchi (2012) showed that the value of GHG emission in crude Jatropha curcas oil (CJCO) extraction process is estimated to be $1.34 \mathrm{~kg}-\mathrm{CO}_{2} / \mathrm{kg}-\mathrm{CJCO}$ and 0.08 $\mathrm{kg}-\mathrm{CO}_{2} / \mathrm{kg}-\mathrm{BDF}[10],[12]$. In this research, the GWP value is $18.65 \mathrm{~kg}-\mathrm{CO}_{2}$ eq./ton-BDF with assumption which assume that drying is carried out naturally (sun drying).

Life cycle of oil palm is about 25 years [9]; [5], while Jatropha curcas can reach up to 50 years (Pranowo 2009; Ferry 2009; Tjahjana et al. 2010) even the productivity of Jatropha curcas is stable until the $25^{\text {th }}$ year. From Fig. 3 and Fig.4, it can be seen that the GWP value for oil palm is higher than Jatropha curcas in every stages except for planting and biodiesel production stages. The most significant environmental impact based on GWP value is caused by fertilizing and biodiesel production stages both at oil palm and Jatropha curcas. The total value of GWP emission before stable productivity is 2568.82 and 1733.67 $\mathrm{kg}-\mathrm{CO}_{2}$ eq./ton-BDF for oil palm and Jatropha curcas, respectively.

Fig. 3 shows that oil palm's GWP value of eight subprocesses which consist of land preparation, seedling, planting, fertilizing, protection, harvesting, palm oil mills, and biodiesel production is $0.44 \%, 0.61 \%, 0.91 \%, 35.15 \%$, $15.31 \%, 1.23 \%, 22.90 \%$, and $23.44 \%$, respectively. While for Jatropha curcas as shown in Fig. 4 is $0.63 \%, 0.74 \%$, $11.79 \%, 29.49 \%, 4.02 \%, 0.48 \%, 1.08 \%$, and $51.78 \%$, respectively. Table 4 shows the proportion of each stage which was regroupped into pre-harvest, harvesting and postharvest.

Lord et al. (2009) stated that environmental impact towards aquatic, land, air and others of palm oil processing from operation to processing stage was $47 \%, 24 \%, 8 \%$, and $21 \%$, respectively. Prueksakorn et al. (2006) said that the major contribution of greenhouse gas (GHG) effect during biodiesel production from jatropha comes from the production and use of fertilizers, diesel oil consumption for irrigation, and transesterification process which is accounted for $31 \%, 26 \%$, and $24 \%$, respectively.

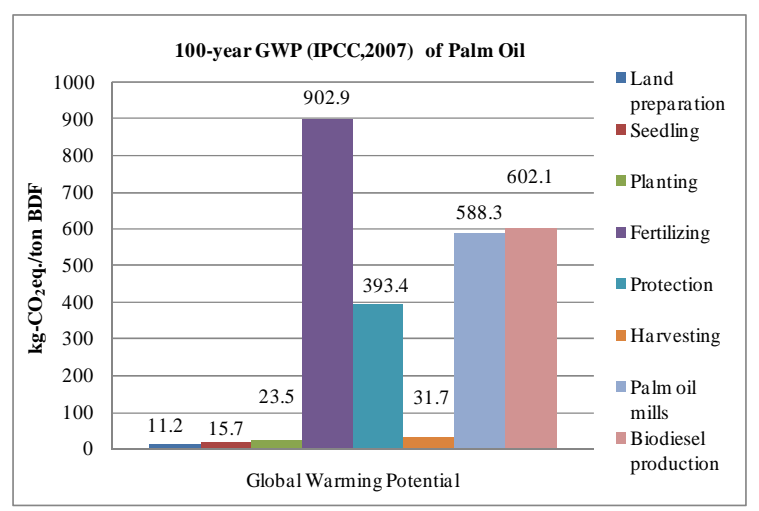

Fig.3. The total value of GWP for oil palm before stable productivity 




Fig.4. The total value of GWP for Jatropha curcas before stable productivity

TABLE III

ENVIRONMENTAL IMPACTS FOR PRODUCING 1 TON BDF FROM PALM OIL AND JATROPHA CURCAS OIL

\begin{tabular}{|c|c|c|c|c|}
\hline $\begin{array}{c}\text { Input } \\
\text { activities }\end{array}$ & Input names & Unit & Palm oil & $\begin{array}{c}\text { Jatropha } \\
\text { curcas }\end{array}$ \\
\hline (1) Land & GWP, 100-year GWP(IPCC, 2007) & $\mathrm{kg}-\mathrm{CO} 2 \mathrm{e}$ & 11.21 & 10.88 \\
\hline \multirow[t]{4}{*}{ Preparation } & Acidification, DAF(LIME,2006) & $\mathrm{kg}-\mathrm{SO} 2 \mathrm{e}$ & 0.020 & 0.017 \\
\hline & Waste,landfill volume(LIME,2006) & & $4.9 \mathrm{E}-06$ & 5.7E-06 \\
\hline & Eutropication, EPMC(LIME,2006) & $\mathrm{kg}-\mathrm{PO} 4 \mathrm{e}$ & $1 \mathrm{E}-06$ & $1.18 \mathrm{E}-06$ \\
\hline & Energy consumption,(fossil fuel) & MJ & 163.41 & 161.66 \\
\hline \multirow[t]{5}{*}{ (2) Seedling } & GWP, 100-year GWP(IPCC, 2007) & $\mathrm{kg}-\mathrm{CO} 2 \mathrm{e}$ & 15.73 & 12.81 \\
\hline & Acidification, DAF(LIME,2006) & $\mathrm{kg}-\mathrm{SO} 2 \mathrm{e}$ & 0.026 & 0.021 \\
\hline & Waste,landfill volume(LIME,2006) & & $9.57 \mathrm{E}-05$ & $1.62 \mathrm{E}-04$ \\
\hline & Eutropication, EPMC(LIME,2006) & $\mathrm{kg}-\mathrm{PO} 4 \mathrm{e}$ & $1.9 \mathrm{E}-06$ & $1.34 \mathrm{E}-06$ \\
\hline & Energy consumption,(fossil fuel) & MJ & 242.94 & 186.28 \\
\hline \multirow[t]{5}{*}{ (3) Planting } & GWP, 100-year GWP(IPCC, 2007) & $\mathrm{kg}-\mathrm{CO} 2 \mathrm{e}$ & 23.46 & 204.38 \\
\hline & Acidification, DAF(LIME,2006) & $\mathrm{kg}-\mathrm{SO} 2 \mathrm{e}$ & 0.04 & 0.40 \\
\hline & Waste,landfill volume(LIME,2006) & $\mathrm{m} 3$ & \#\#\#\#\# & 0.0044 \\
\hline & Eutropication, EPMC(LIME,2006) & $\mathrm{kg}-\mathrm{PO} 4 \mathrm{e}$ & $2.9 \mathrm{E}-06$ & 4.17E-05 \\
\hline & Energy consumption,(fossil fuel) & MJ & 387.40 & $3,394.34$ \\
\hline \multirow[t]{5}{*}{ (4) Fertilizing } & GWP, 100-year GWP(IPCC, 2007) & $\mathrm{kg}-\mathrm{CO} 2 \mathrm{e}$ & 902.90 & 511.27 \\
\hline & Acidification, DAF(LIME,2006) & $\mathrm{kg}-\mathrm{SO} 2 \mathrm{e}$ & 1.02 & 0.81 \\
\hline & Waste,landfill volume(LIME,2006) & $\mathrm{m} 3$ & 0.0071 & 0.0088 \\
\hline & Eutropication, EPMC(LIME,2006) & $\mathrm{kg}-\mathrm{PO} 4 \mathrm{e}$ & $5.8 \mathrm{E}-05$ & 0.000074 \\
\hline & Energy consumption,(fossil fuel) & MJ & 18240.00 & 10841.11 \\
\hline \multirow[t]{5}{*}{ (5) Protection } & GWP, 100-year GWP(IPCC, 2007) & $\mathrm{kg}-\mathrm{CO} 2 \mathrm{e}$ & 393.38 & 69.64 \\
\hline & Acidification, DAF(LIME,2006) & $\mathrm{kg}-\mathrm{SO} 2 \mathrm{e}$ & 0.69 & 0.21 \\
\hline & Waste,landfill volume(LIME,2006) & & 0.00067 & 0.0011 \\
\hline & Eutropication, EPMC(LIME,2006) & $\mathrm{kg}-\mathrm{PO} 4 \mathrm{e}$ & $6.9 \mathrm{E}-05$ & 8.93E-06 \\
\hline & Energy consumption,(fossil fuel) & MJ & 6211.61 & 1178.64 \\
\hline \multirow[t]{5}{*}{ (6) Harvesting } & GWP, 100-year GWP(IPCC, 2007) & $\mathrm{kg}-\mathrm{CO} 2 \mathrm{e}$ & 31.67 & 8.27 \\
\hline & Acidification, DAF(LIME,2006) & $\mathrm{kg}-\mathrm{SO} 2 \mathrm{e}$ & 0.058 & 0.015 \\
\hline & Waste,landfill volume(LIME,2006) & $\mathrm{m} 3$ & $1.1 \mathrm{E}-08$ & $2.86 \mathrm{E}-09$ \\
\hline & Eutropication, EPMC(LIME,2006) & $\mathrm{kg}-\mathrm{PO} 4 \mathrm{e}$ & $9.5 \mathrm{E}-11$ & $2.47 \mathrm{E}-11$ \\
\hline & Energy consumption,(fossil fuel) & MJ & 422.55 & 110.38 \\
\hline \multirow{5}{*}{$\begin{array}{l}\text { (7) Palm oil } \\
\text { mills or } \\
\text { Extraction oil }\end{array}$} & GWP, 100-year GWP(IPCC, 2007) & $\mathrm{kg}-\mathrm{CO} 2 \mathrm{e}$ & 588.34 & 18.65 \\
\hline & Acidification, DAF(LIME,2006) & $\mathrm{kg}-\mathrm{SO} 2 \mathrm{e}$ & 0.98 & 0.053 \\
\hline & Waste,landfill volume(LIME,2006) & $\mathrm{m} 3$ & 0.00082 & $5.24 \mathrm{E}-06$ \\
\hline & Eutropication, EPMC(LIME,2006) & $\mathrm{kg}-\mathrm{PO} 4 \mathrm{e}$ & 0.000064 & 7.49E-06 \\
\hline & Energy consumption,(fossil fuel) & $\mathrm{MJ}$ & 7994.14 & 234.18 \\
\hline \multirow{5}{*}{$\begin{array}{l}\text { (8) Biodiesel } \\
\text { production }\end{array}$} & GWP, 100-year GWP(IPCC, 2007) & $\mathrm{kg}-\mathrm{CO} 2 \mathrm{e}$ & 602.12 & 897.77 \\
\hline & Acidification, DAF(LIME,2006) & $\mathrm{kg}-\mathrm{SO} 2 \mathrm{e}$ & 0.72 & 0.98 \\
\hline & Waste,landfill volume(LIME,2006) & & 0.00031 & 0.00052 \\
\hline & Eutropication, EPMC(LIME,2006) & $\mathrm{kg}-\mathrm{PO} 4 \mathrm{e}$ & 0.000047 & 0.000059 \\
\hline & Energy consumption,(fossil fuel) & MJ & 16169.11 & 25623.45 \\
\hline \multirow[t]{5}{*}{ Total } & GWP, 100-year GWP(IPCC, 2007) & $\mathrm{kg}-\mathrm{CO} 2 \mathrm{e}$ & 2568.82 & 1733.67 \\
\hline & Acidification, DAF(LIME,2006) & $\mathrm{kg}-\mathrm{SO} 2 \mathrm{e}$ & 3.55 & 2.50 \\
\hline & Waste,landfill volume(LIME,2006) & & 0.0094 & 0.015 \\
\hline & Eutropication, EPMC(LIME,2006) & kg-PO4 & 0.00024 & 0.00019 \\
\hline & Energy consumption,(fossil fuel) & MJ & 49831.17 & 41730.03 \\
\hline
\end{tabular}

Prueksakorn et al. (2006) also explained that $\mathrm{CO}_{2}$ emissions for producing biodiesel from crude jatropha oil with transesterification method is generated from land preparation, cultivation, irrigation, fertilizing, cracking, extraction oil, filtering, and transesterification process which is accounted for $4.7 \%, 0.2 \%, 26.1 \%, 30.3 \%, 3 \%, 10.9 \%$, $0.5 \%$ and $24.3 \%$, respectively. Ndong et al. (2009) gives the details of GHG emissions in the various processes as follows: the cultivation of jatropha is accounted for $52 \%$ of total emissions, while transesterification and combustion phase are $17 \%$ and $16 \%$, respectively. Large emissions occur in fertilizer application, were estimated to be $93 \%$.

Fig.5 and Fig.6, show that energy consumption for palm oil is higher than Jatropha curcas in every stages except for planting and biodiesel production. The largest energy consumption for Jathropa curcas occurs in biodiesel production sub-process i.e. 25623.45 MJ/ton-BDF. While the largest energy consumption for oil palm is fertilizing sub-process i.e. $18240.0 \mathrm{MJ} /$ ton-BDF. However, energy consumption in biodiesel production sub-process of Jatropha curcas oil is higher than that of palm oil due to higher free fatty acid (FFA) content which needs esterification process prior to the transesterification process. The total value of energy consumption before stable productivity for oil palm and Jatropha curcas is 49831.17 and $41730.03 \mathrm{MJ} /$ ton-BDF, respectively.

TABLE IV

PERCENTAGE OF GWP-100 YeARS FOR LCA WITH BOUNDARY CRADLE TO GATE AT OIL PALM AND JATROPHA CURCAS

\begin{tabular}{|l|c|c|}
\hline \multirow{2}{*}{ Input activities } & \multicolumn{2}{|c|}{ Percentage (\%) } \\
\cline { 2 - 3 } & Palm oil & Jatropha curcas \\
\hline Pre-harvest & 52.42 & 46.66 \\
\hline Harvesting & 1.23 & 0.48 \\
\hline Post-harvest & 46.34 & 52.86 \\
\hline
\end{tabular}

Fig.5 shows that oil palm energy consumption during land preparation, seedling, planting, fertilizing, protection, harvesting, palm oil mills, and biodiesel production is $0.33 \%$, $0.49 \%, 0.78 \%, 36.60 \%, 12.47 \%, 0.85 \%, 16.04 \%$, and $32.45 \%$, respectively. While for Jatropha curcas, the value of each sub process is $0.39 \%, 0.45 \%, 8.13 \%, 25.98 \%, 2.82 \%$, $0.26 \%, 0.56 \%$, and $61.4 \%$, respectively. Table 5 shows the proportion of each stage which comprised into pre-harvest, harvesting and post-harvest. Prueksakorn et al. (2006) also explained that energy consumption needed for transesterification is higher than fertilization. On the contrary, fertilization is higher in greenhouse gas emissions. It occurs because of the $\mathrm{N}$ compound and because the use of $\mathrm{N}_{2} \mathrm{O}$ has strong effects on GHG.

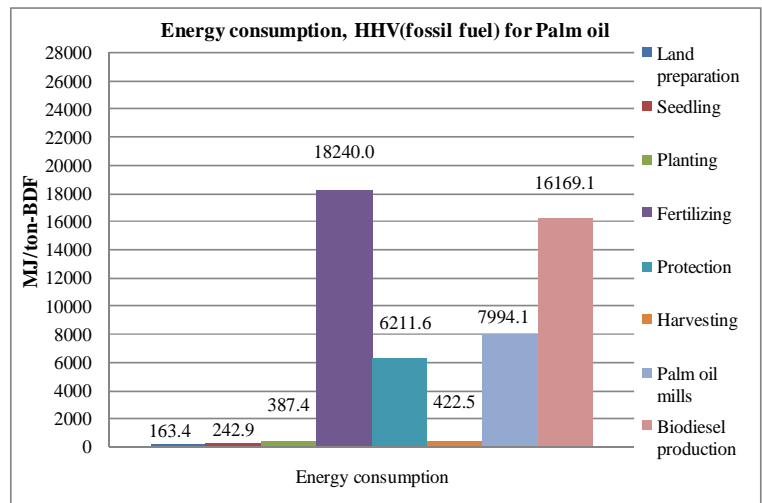

Fig.5. The total value of energy consumption for oil palm before stable productivity 




Fig.6. The total value of energy consumption for Jatropha curcas before stable productivity

TABLE V

PERCENTAGE OF ENERGY CONSUMPTION FOR LCA WiTH BOUNDARY Cradle To Gate At Oil Palm And Jatropha CuRCas

\begin{tabular}{|l|c|c|}
\hline \multirow{2}{*}{ Input activities } & \multicolumn{2}{|c|}{ Percentage (\%) } \\
\cline { 2 - 3 } & Palm oil & Jatropha curcas \\
\hline Pre-harvest & 50.66 & 37.77 \\
\hline Harvesting & 0.85 & 0.26 \\
\hline Post-harvest & 48.49 & 61.96 \\
\hline
\end{tabular}

Fig.7 and Fig.8 show that GWP emission at stable productivity (6 to 25 years) is 1658.50 and $740.90 \mathrm{~kg}-\mathrm{CO}_{2}$ eq./ton-BDF for oil palm and jatropha curcas, respectively. The energy consumption for fossil fuel at stable productivity is 33190.05 and $19395.89 \mathrm{MJ} /$ ton-BDF for oil palm and Jatropha curcas, respectively. The GWP value and energy consumption of oil palm and Jatropha curcas is decreasing until the $5^{\text {th }}$ year and stable from there until the $25^{\text {th }}$ year.



Fig.7. The value of GWP for oil palm and Jatropha curcas before and after stable productivity

Similar trend emerges in impact assessment also occurs at acidification, eutrophication, and landfill waste as shown in Fig.9, Fig.10, and Fig.11. Assessment conducted by Sekiguchi (2012) shows that total $\mathrm{CO}_{2}$ emission is 0.46 $\mathrm{CO}_{2}$ eq. $/ \mathrm{kg}$-BDF for SMV method, $0.79 \mathrm{CO}_{2}$ eq. $/ \mathrm{kg}$-BDF for alkali-catalyzed method and $3.4 \mathrm{CO}_{2}$ eq./kg-diesel for diesel oil. The result differences might be due the differences in methods and assumptions adopted in the studies.



Fig.8.The value of energy consumption for oil palm and Jatropha curcas before and after stable productivity

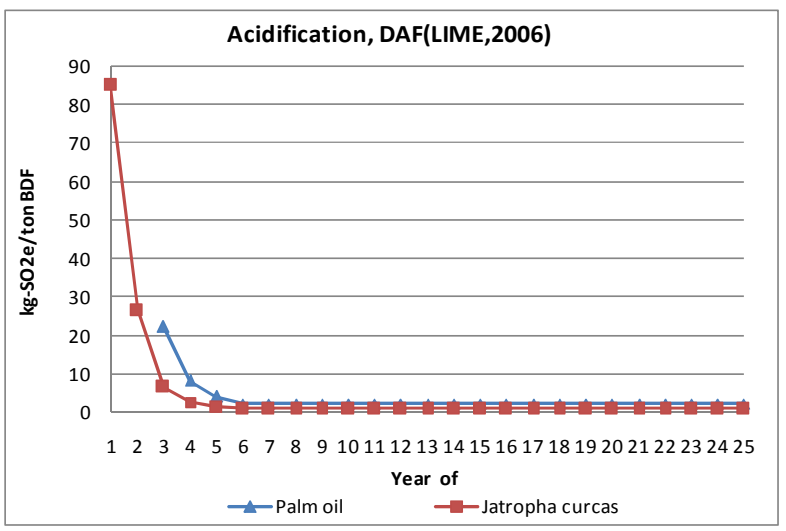

Fig.9.The value of acidification for oil palm and Jatropha curcas before and after stable productivity

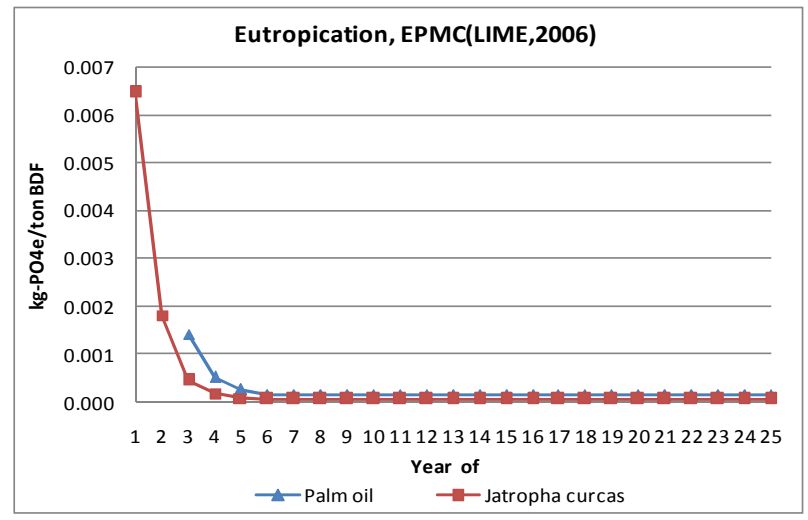

Fig.10.The value of eutrophication for oil palm and Jatropha curcas before and after stable productivity



Fig.11.The value of waste landfill volume for oil palm and Jatropha curcas before and after stable productivity 
Fig. 12, Fig. 13, and Fig. 14 show comparison between reduction value of $\mathrm{CO}_{2}$ emission produced in oil palm and Jathropa curcas towards diesel oil. Fig. 12 and Fig. 13 show that reduction in $\mathrm{CO}_{2}$ emissions is greater at stable productivity due to lower input energy and mass which only used for maintenance, fertilizing and harvesting. The subprocesses of land preparation, seedling, and planting are not carried out in this phase.

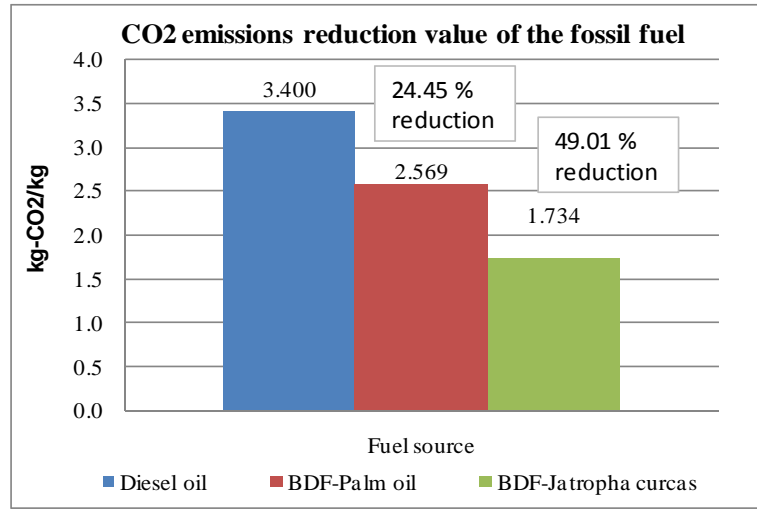

Fig.12. The reduction values of $\mathrm{CO}_{2}$ emission before stable productivity

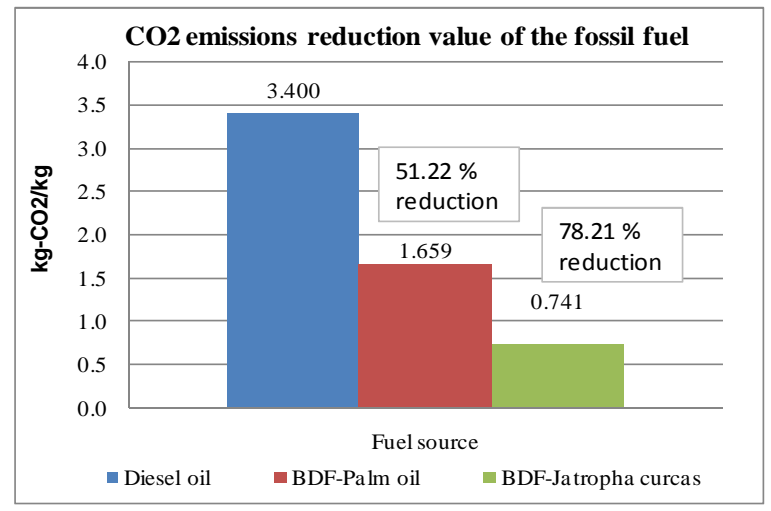

Fig.13. The reduction values of $\mathrm{CO}_{2}$ emission after stable productivity

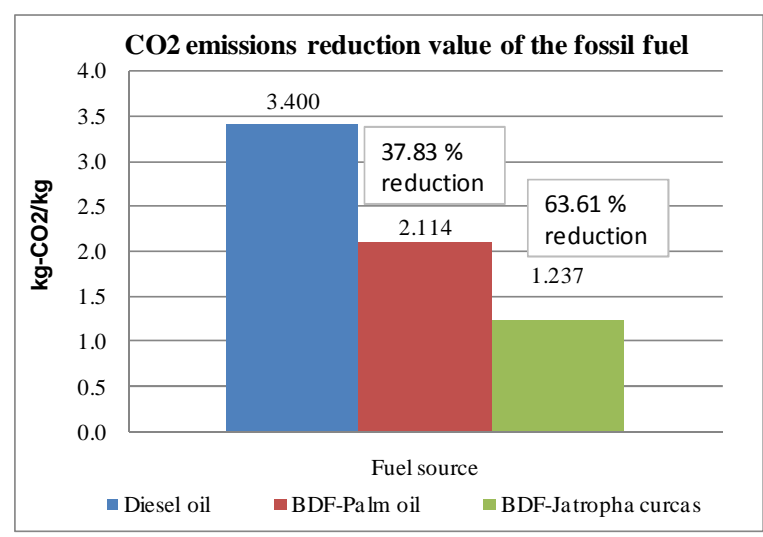

Fig.14. The total values of $\mathrm{CO}_{2}$ emission

Fig. 14 shows combination values of $\mathrm{CO}_{2}$ emission before and after stable production. It can be seen that reduction value of $\mathrm{CO}_{2}$ emissions for BDF-CPO and BDF-CJCO is $37.83 \%$ and $63.61 \%$, respectively. Research conducted by Gomma et al. (2011) mentioned that biodiesel of jatropha can save greenhouse gas emission by $66 \%$ compared with diesel fuel even it accounts pasture land use. Prueksakorn et al. [7] stated that greenhouse gas emission is $77 \%$ lower than production and diesel fuel consumption.

\section{CONCLUSIONS}

Total environmental impact for biodiesel production from palm oil is higher than that of Jatropha curcas oil. Utilization of agrochemical in form of fertilizer and plant protection generate significant contribution to environmental impact of biodiesel production i.e. $50.46 \%$ and $33.51 \%$ for palm oil and Jatropha curcas oil, respectively. GWP emission until 5 years of plantation is $1695.36 \mathrm{~kg}$ $\mathrm{CO}_{2}$ eq./ton-BDF and $740.90 \mathrm{~kg}-\mathrm{CO}_{2}$ eq./ton-BDF for palm oil and Jatropha curcas oil, respectively. After stable production, $\mathrm{CO}_{2}$ emission of diesel fuel decreases up to $37.83 \%$ and $63.61 \%$ for BDF-CPO and BDF-CJCO, respectively.

\section{ACKNOWLEDGMENT}

Thank you very much to Prof.Dr.Armansyah H.Tambunan,M.Agr, Dr.Ir.Abdul Kohar,M.Sc, Dr.Ir.Soni Solistia Wirawan,M.Ec, and Prof.Tetsuya Araki,Ph.D as my academic advisor in Bogor Agricultural university.

\section{REFERENCES}

[1] Ciambrone DF (1997) Environmental Life Cycle Analysis. Florida: CRC Press LLC.

[2] Ferry Y (2009) Budidaya Jarak pagar (Jatropha curcas L). Estate Crops Research and Development Centre Bogor, Indonesia

[3] Gomaa M, Alimin AJ, Kamarudin KA (2011) The effect of EGR rates on NOx and smoke emmisions of an IDI diesel engine fuelled with Jatropha biodiesel blends, International Journal of Energy and Enviroment, Vol.2, Issue 3, 2011, pp.477-490

[4] Lord S, Clay J (2009) Enviromental Impacts of Oil palm-Practical Considerations in Defining Sustinaibility for Impacts on the Air, Land and Water, USA

[5] Lubis RE, Widanarko A (2011) Smart palm oil : Agromedia Jakarta, Indonesia

[6] Ndong R, Vignoles MM, Girons OS, Gabrielles B, Pirot R, Domergue M, Sablayrolles C (2009) Life cycle assessment of biofuels from Jatropha curcas in West Africa : a field study, GCB Bioenergy (2009) 1, pp. 197-210, doi:10.1111/j.17571707.2009.01014.x

[7] Prueksakorn K, Gheewala SH (2006) Energy and Green house gas Implications of Biodiesel Production from Jatropha curcas L.. The 2nd Joint International Conference on "Sustainable Energy and Environment (SEE 2006)-Bangkok, Thailand, 21-23 November 2006

[8] Pranowo D (2009) Jatropha Cultivation Technology (Jatropha curcas L). Estate Crops Research and Development Centre Bogor, Indonesia

[9] Pahan IA (2011) Complete guide palm-agribusiness management from up stream to downstream, Jakarta, Indonesia

[10] Pramudita D (2011) Life cycle inventory analysis of postharvest handling and extraction of Jatropha curcas oil, Graduation Thesis, Bogor Agricultural University (in Indonesia)

[11] Searcy C (2000) An Introduction to Life Cycle Assessment. http://www.i-clps.com/lca/

[12] Sekiguchi T (2012) Possibilities and limitations in disseminating outcomes of technological development to utilize biomass for liquid fuel, Master Thesis, The University of Tokyo (in Japanese)

[13] Tjahjana BE, Pranowo D (2010) Cultivation and processing of Primary Jatropha curcas primary, Publishing and publication unit, Balitri Pakuwon Sukabumi, Indonesia

[14] Tambunan AH, Situmorang JP, Silip JJ, Joelianingsih A, Araki T (2012) Yield and physico chemical properties of mechanically extracted crude Jatropha curcas L oil, Biomass and Bioenergy, 43, 2012, pp.12-17. 